\title{
Improvement of Rice (Oryza sativa L.) var. Ciherang and Cempo Ireng Productivity Using Gamma Irradiation
}

\author{
Fitri Masruroh $^{1}$, Samanhudi ${ }^{2}$, Sulanjari ${ }^{2}$ and Ahmad Yunus ${ }^{2}$ \\ 1. Study Program of Agronomy, Graduate School of Sebelas Maret University, Surakarta 57126, Indonesia \\ 2. Department of Agrotechnology, Faculty of Agriculture, Sebelas Maret University, Surakarta 57126, Indonesia
}

\begin{abstract}
Rice is the source of important food in the world. The demand of rice tends to increase every year, thus research to increase genetic variation of rice by gamma irradiation has been conducted. This research aimed to study the influence of gamma irradiation doses on the vegetative growth, yield and quality. The randomized completely block design was used with two factors - gamma irradiation doses and varieties. Two rice varieties were Ciherang and Cempo Ireng, while doses of gamma irradiation consisted of six levels: 0, 100, 200, 300, 400 and 500 Gy. The results indicated that the treatment of 200 Gy gamma irradiation to Ciherang could improve the number of grains/panicle, protein content, degraded plant height and amylose contents. Gamma irradiation to Cempo Ireng at dose of 200 Gy could improve the number of grains/panicle, 1,000 grain weight, while it decreased days to $50 \%$ heading and plant harvest age.
\end{abstract}

Key words: Gamma irradiation, rice (Oryza sativa L.), productivity.

\section{Introduction}

Rice (Oryza sativa L.) is the source of important food in the world. The demand of rice tends to increase every year. In 2025, Indonesia's population will be projected to reach approximately 300 million, and very large quantities of rice will be required. In 2014, the Indonesian government has targeted rice production as much as 75.7 million tons of milled rice [1]. The developed potential of rice varieties is local rice variety Cempo Ireng. The local rice cultivars were long-lived and generally poor in crop harvest [2].

Ciherang is commercial rice variety released in Indonesia on 2000. It is an indica rice with yield potential of 5-8 ton/ha, resistant to brown plant hopper biotype 2 and 3, resistant to bacterial leaf blight, height plant of 107-115 cm, plant age of 116-125 d, and suitable for land with altitude under $500 \mathrm{~m}$ above the sea level [3]. Cempo Ireng is black rice, with height of plant until $190 \mathrm{~cm}$, the age of plant is $150 \mathrm{~d}$, and glycemic index is low (50-60), but with high

Corresponding author: Ahmad Yunus, professor, research field: plant biotechnology. anthocyanin [4].

The purpose of plant breeding is to improve properties of plants that superior to existing plants [5]. Wahdah et al. [2] declared that the high yield and early maturity age were the major factors in increasing rice production through plant breeding to support the sustainability of food security and self-sufficiency in rice.

The technique that could be used to obtain superior varieties is by crossbreeding and mutation [6]. The advantage of using gamma rays is the more accurate dosage and radiation penetration into cells is homogeneous. Mutation induction using irradiation produces more mutant (approximately 75\%) when compared to using other treatments, such as chemical mutagen [7]. Mustikarini et al. [8] reported that gamma irradiation doses of 200 Gy can shorten plant harvest age, for example, $24 \mathrm{~d}$ on the local red rice, from Bangka Island, Runteh Puren. Harsanti and Mugiono [9] concluded that mutant strains of paddy variety Cimelati as a result of gamma irradiation have character of early duration and high production. Pandan Putri mutants have short age 120 d compared 
to control that have $165 \mathrm{~d}$ [10]. Sulutan Unsrat I and II have harvesting age $111 \mathrm{~d}$ and $112 \mathrm{~d}$ with yield potential 8 ton/ha [11].

This study aimed to study the effect of doses of gamma irradiation on growth, yield and harvesting age of rice Ciherang and Cempo Ireng, as well as to determine the dose of gamma radiation that could potentially generate mutant with better properties of plant origin, especially shorter harvest age and high production.

\section{Materials and Methods}

The experiment was conducted in July until December 2014 under the paddy field in Dlingo, Mojosongo, Boyolali. Ciherang seeds were obtained from Agency of Testing and Certification Seeds, Tegalgondo, while Cempo Ireng seeds were obtained from Sleman, Yogyakarta. The randomized completely block design was used with two factors - gamma irradiation doses and varieties. Rice varieties are Ciherang and Cempo Ireng, while doses of gamma irradiation consist of six levels: 0, 100, 200, 300, 400 and 500 Gy. The gamma irradiation procedure was performed at Centre for Application of Isotopes and Radiation Technology (PATIR), Indonesian National Nuclear Energy Agency (BATAN), Jakarta, following the steps described by Mugiono et al. [6]. Gamma irradiation was emitted from radioactive cobalt-60 $\left({ }^{60} \mathrm{Co}\right)$ using a gamma irradiator chamber $4000 \mathrm{~A}$ in accordance with a predetermined doses.

The variables measured consist of plant height, number of grains per panicle, weight of 1,000 grains, days to flowering, plant harvest age, amylose contents, protein contents and anthocyanin contents.

Data on field were obtained from three plants and analyzed using analysis of variance (ANOVA) by $\mathrm{F}$ test level of $5 \%$, and the averages between treatments were compared using Duncan's multiple range test (DMRT) at the level of $5 \%$ on the normal data. The abnormal data were analyzed with the Kruskal-Wallis test and the mood median test was to compare averages between treatments.

\section{Results and Discussion}

\subsection{Effect of Gamma Irradiation on Plant Height}

The property of rice plants with shorter height is advantageous quality in breeding rice plants. Based on the data in Table 1, the higher dose of gamma irradiation causes the shorter plants in Ciherang rice. According to Sasilakala and Kalaiyarasi [12], plant height decreased with increasing doses of gamma irradiation with a linear pattern. While the different results are shown in Cempo Ireng rice (Table 1), where the decrease in plant height occurred at gamma

Table 1 The effect of gamma irradiation doses on the growth and yield of Ciherang and Cempo Ireng rice.

\begin{tabular}{|c|c|c|c|c|c|}
\hline Varieties & $\begin{array}{l}\begin{array}{l}\text { Doses } \\
\text { (Gy) }\end{array} \\
\end{array}$ & $\begin{array}{l}\text { Plants height } \\
(\mathrm{cm})\end{array}$ & $\begin{array}{l}\text { Weight of } 1,000 \text { grains } \\
\text { (g) }\end{array}$ & $\begin{array}{l}\text { Flowering age } \\
\text { (days after sowing) }\end{array}$ & $\begin{array}{l}\text { Harvest age } \\
\text { (days after sowing) }\end{array}$ \\
\hline \multirow{6}{*}{ Ciherang } & 0 & $98.67^{c}$ & $24.89^{c}$ & $103.67^{\mathrm{a}}$ & $128.67^{\mathrm{a}}$ \\
\hline & 100 & $90.78^{\mathrm{b}}$ & $25.77^{\mathrm{c}}$ & $100.33^{\mathrm{a}}$ & $125.33^{\mathrm{a}}$ \\
\hline & 200 & $85.22^{\mathrm{b}}$ & $25.91^{\mathrm{c}}$ & $104.00^{\mathrm{ab}}$ & $129.00^{\mathrm{ab}}$ \\
\hline & 300 & $84.22^{b}$ & $25.23^{c}$ & $101.00^{\mathrm{a}}$ & $126.00^{\mathrm{a}}$ \\
\hline & 400 & $71.22^{\mathrm{a}}$ & $20.98^{\mathrm{b}}$ & $105.67^{\mathrm{ab}}$ & $130.67^{\mathrm{ab}}$ \\
\hline & 500 & $62.00^{\mathrm{a}}$ & $17.85^{\mathrm{a}}$ & $104.67^{\mathrm{ab}}$ & $129.67^{\mathrm{ab}}$ \\
\hline \multirow{6}{*}{ Cempo Ireng } & 0 & $136.11^{\mathrm{d}}$ & $23.01^{\mathrm{b}}$ & $125.00^{c}$ & $155.00^{c}$ \\
\hline & 100 & $134.11^{\mathrm{d}}$ & $25.84^{c}$ & $119.00^{\mathrm{bc}}$ & $149.00^{\mathrm{bc}}$ \\
\hline & 200 & $136.56^{\mathrm{d}}$ & $24.42^{c}$ & $114.67^{\mathrm{b}}$ & $144.67^{\mathrm{b}}$ \\
\hline & 300 & $135.33^{d}$ & $21.53^{\mathrm{b}}$ & $115.00^{\mathrm{b}}$ & $145.00^{\mathrm{b}}$ \\
\hline & 400 & $120.11^{c}$ & $18.69^{b}$ & $122.33^{\mathrm{bc}}$ & $152.33^{\mathrm{bc}}$ \\
\hline & 500 & $120.56^{\mathrm{c}}$ & $17.23^{\mathrm{a}}$ & $117.33^{\mathrm{b}}$ & $147.33^{\mathrm{b}}$ \\
\hline
\end{tabular}

Means followed with the same letter in the same column had no significant difference on mood median test level of $5 \%$. 
irradiation of doses 300, 400 and 500 Gy. Daeli et al. [13] declared that the exposure of gamma irradiation above 300 Gy could cause a short and dwarf plants. Cempo Ireng is likely more resistant to doses of gamma irradiation until 300 Gy (Table 1).

\subsection{Effect of Gamma Irradiation on the Number of Grains}

The data in Table 2 showed that 200 Gy irradiation dose resulted the highest number of grains per panicle on Ciherang and Cempo Ireng rice (169.78 and 168.33, respectively). As shown in Fig. 1, the results of the correlation analysis between panicle length and the number of grains per panicle showed that the panicle length was positively correlated with the number of grains per panicle with correlation coefficients $r=$ 0.922. This shows that the longer of panicle length causes increase in the number of grains per panicle.

The research results of Gnanamurthy et al. [14] showed that $25 \mathrm{krad}$ (250 Gy) of gamma irradiation produced the highest weight of 1,000 grains compared with other treatments. Based on the analysis in Table 1, in Ciherang rice, 400 Gy and 500 Gy gamma radiation decreased the weight of 1,000 grains, while doses of $100 \mathrm{~Gy}$ and $200 \mathrm{~Gy}$ could be capable to increase the weight of 1,000 grains in Cempo Ireng.

\subsection{Effect of Gamma Irradiation on Flowering Age}

El-Degwy [15] declared that the doses of gamma irradiation had very significant effect on flowering date. According to Table 1, the treatments of gamma irradiation doses showed different results on the varieties of Ciherang and Cempo Ireng. The Ciherang variety experienced almost the same age flower, whereas the variety Cempo Ireng on the treatment of radiation doses of $200 \mathrm{~Gy}$ and $300 \mathrm{~Gy}$ could potentially produce a mutant, which has a lifespan of early flowering. This indicates that mutation has occurred due to radiation exposure of gamma rays, which causes changes in chromosome structure, thus affecting emerge properties, i.e., flowering date.

Table 2 The analysis results of number of grains per panicle in Ciherang and Cempo Ireng rice.

\begin{tabular}{llll}
\hline Doses (Gy) & Ciherang & Cempo Ireng & Mean \\
\hline 0 & 119.89 & 125.78 & $122.83^{\mathrm{a}}$ \\
100 & 148.44 & 164.78 & $156.61^{\mathrm{b}}$ \\
200 & 169.78 & 166.33 & $168.06^{\mathrm{c}}$ \\
300 & 127.22 & 132.33 & $129.78^{\mathrm{ab}}$ \\
400 & 102.33 & 117.44 & $109.89^{\mathrm{a}}$ \\
500 & 81.67 & 123.56 & $102.61^{\mathrm{a}}$ \\
\hline
\end{tabular}

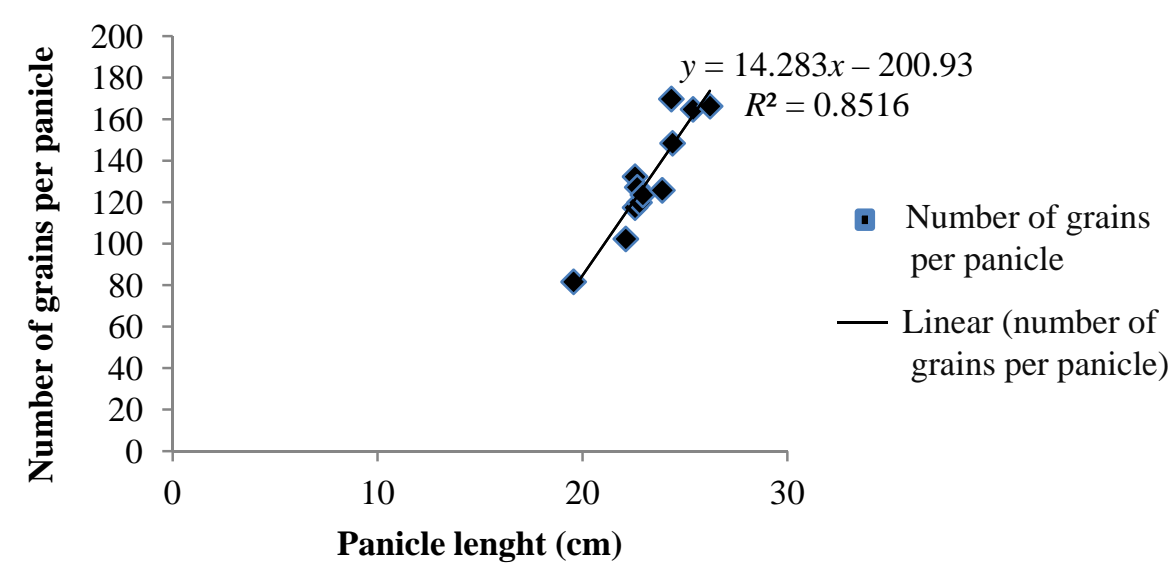

Fig. 1 Relationship between panicle length and the number of grains per panicle. 


\subsection{Effect of Gamma Irradiation on Harvested Age}

Based on the correlation analysis, harvest age was positively correlated with flowering date with the correlation coefficient $r=0.994$. This suggests that the longer flowering date would cause a longer harvest age, too. Sianipar et al. [16] stated that the dosage of gamma irradiation had significantly effect on the harvest age.

Based on the data in Table 1, the harvest age of Ciherang rice in all treatment of gamma irradiation was not significantly different from the control. While the Cempo Ireng rice treated with doses 200 Gy and 300 Gy had a mean harvest age of 10-11 d earlier than that without the gamma irradiation treatment. Daeli et al. [13] declared that the average of the fastest harvest age appeared in the radiation treatment of $10 \mathrm{krad}$ (100 Gy). The radiation could cause changes in the arrangement of chromosomes and DNA, thus stimulating the emergence of mutations that affect the metabolism of plant growth. One of the affected metabolism is the process of photosynthesis, so that the supply of nutrients which plants need to produce seeds affects the harvest age.

\subsection{Effect of Gamma Irradiation on Biochemical Characteristics}

One of the nutrients that reflect the quality of the rice yield is the protein content. Based on the analysis in Table 3, the average of protein content in Cempo Ireng rice amounted to $8.12 \%$, which is higher than Ciherang rice $(7.67 \%)$. On Ciherang rice, the enhancement of protein content appeared on all of the radiation dose compared with controls. While on Cempo Ireng rice, increased levels of protein appeared at treatment doses of $400 \mathrm{~Gy}$ and $500 \mathrm{~Gy}$. According to Widyantoro et al. [17], 75 Gy gamma irradiation increased the protein content of corn $12 \%$ higher than the control. Dehpour et al. [18] reported that the difference in doses of gamma irradiation had a different effect on the biochemical characteristics of plants, such as, increased content of proline and protein.

In Ciherang rice, the treatment of gamma irradiation at doses of $100 \mathrm{~Gy}$ and 300 Gy could cause increase of amylose content, whereas the doses of 200, 400 and 500 Gy lead amylose content decrease (Table 3). In general, the treatment of gamma irradiation on Cempo Ireng rice could increase amylose content, except at doses of 200 Gy and 400 Gy. According to Ashwar et al. [19], gamma irradiation dose of 200 Gy caused a decrease in amylose content of $23 \%$ to $20.62 \%$. Decreased amylose content then affected the rice texture, i.e., causing that the rice texture becomes fluffier. The mean amylose content on Ciherang rice is $19.44 \%$, whereas on Cempo Ireng rice is $15.53 \%$. This suggests that the Cempo Ireng rice tends to be fluffier than Ciherang rice.

The anthocyanin level of Ciherang (white rice) was not analyzed due to its low content of anthocyanin. The analysis results of anthocyanin levels in Cempo Ireng black rice showed that the doses treatment of gamma irradiation of 100 Gy and 500 Gy increased the levels of anthocyanin compared with controls (Table 4). The lowest levels of anthocyanin (4.213\%)

Table 3 The analysis results of protein content and amylase levels in Ciherang and Cempo Ireng rice.

\begin{tabular}{llll}
\hline Varieties & $\begin{array}{l}\text { Doses } \\
(\mathrm{Gy})\end{array}$ & $\begin{array}{l}\text { Protein contents } \\
(\%)\end{array}$ & $\begin{array}{l}\text { Amylase levels } \\
(\%)\end{array}$ \\
\hline \multirow{4}{*}{ Ciherang } & 0 & 6.258 & 19.67 \\
& 100 & 7.870 & 19.85 \\
& 200 & 8.126 & 18.38 \\
& 300 & 7.003 & 20.24 \\
& 400 & 8.978 & 19.60 \\
\hline Mean & 500 & 7.807 & 18.90 \\
\hline \multirow{4}{*}{ Cempo Ireng } & 0 & 7.673 & 19.44 \\
& 100 & 7.732 & 14.41 \\
& 300 & 7.498 & 22.45 \\
& 400 & 10.237 & 12.84 \\
\hline Mean & & 7.132 & 17.47 \\
\hline
\end{tabular}


Table 4 The effect of gamma irradiation on anthocyanin levels in Cempo Ireng rice.

\begin{tabular}{lll}
\hline No. & $\begin{array}{l}\text { Doses } \\
(\mathrm{Gy})\end{array}$ & $\begin{array}{l}\text { Anthocyanin levels } \\
(\mathrm{ppm})\end{array}$ \\
\hline 1 & 0 & 18.623 \\
2 & 100 & 19.199 \\
3 & 200 & 4.213 \\
4 & 300 & 11.836 \\
5 & 400 & 4.996 \\
6 & 500 & 52.174 \\
\hline
\end{tabular}

was found in plants treated with $200 \mathrm{~Gy}$ gamma irradiation, whereas the highest levels (52.174\%) contained in $500 \mathrm{~Gy}$. El-Sherif et al. [20] reported that the treatment of gamma irradiation at dose of $600 \mathrm{~Gy}$ increased the highest levels of anthocyanin in rosella (Hibiscus sabdariffa).

\section{Conclusions}

The results indicated that gamma irradiation at 200 Gy to Ciherang could improve the number of grains/panicle and protein contents, while it degraded the plant height and the amylose contents. Gamma irradiation to Cempo Ireng at dose of 200 Gy could improve the number of grains per panicle, weight of 1,000 grains and the plant harvest age.

\section{References}

[1] Suswono. 2011. "The Indonesian Food Security in the Perspective of Global Economy and National Sovereignty.” Presented at International Conference on "The Future of Global Food Security and Safety: Issues and Justification”, IPB International Convention Center, Bogor, October 27, 2011.

[2] Wahdah, R., Langai, B. F., and Sitaresmi, T. 2009. "Observation of Variability among Local Rice Varieties of Tidal Swamp Area in South Kalimantan.” Agroscientiae 16 (3): 177-84. (in Indonesia)

[3] Jamil, A., Satoto, Sasmita, P., Baliadi, Y., Guswara, A., and Suharna. 2015. "Description of New Superior Rice Varieties 2015.” Indonesian Center for Rice Research (ICRR). Accessed $\quad$ February, 2015. http://bbpadi.litbang.pertanian.go.id/index.php/en/publikasi /buku/content/item/382-deskripsi-varietas-padi-2015. (in Indonesia)

[4] Widyayanti, K. S., Sudarmaji, S., and Wiranti, E. W. 2015. "Participative Conservation of Local Black Rice in Yogyakarta." In Proceedings of National Seminar on
Agricultural Genetic Resources, 101-9. (in Indonesia)

[5] Human, S. 2011. "Research and Development of Sorghum and Wheat for Food Security.” Application of Isotope and Radiation Technology Center, National Nuclear Energy Agency (BATAN), Jakarta. Accessed October 27, 2011. http://www.opi.lipi.go.id/data/ 1228964432/data/13086710321319802838.makalah.pdf.

[6] Mugiono, Harsantidan, L., and Dewi, A. K. 2009. “The Improvement of Cisantana Rice Variety through Induced Mutation.” Scientific Journal of Isotope and Radiation Applications 5 (2): 194-207.

[7] Monica, S., and Seetharaman, N. 2016. "Gamma Radiation and EMS Induced Genetic Variability on the Improvement of Garden Bean.” Journal of Chemical, Biological and Physical Sciences 7 (1): 77-84.

[8] Mustikarini, E. D., Zasari, M., and Kartika. 2012. "First Mutant Selection (M1) of Red Rice Accession Local Bangka with Treatment Gamma Radiation Dose 200 Gray.” Bachelor thesis, Department of Agrotechnology, Bangka Belitung University, Pangkal Pinang.

[9] Harsanti, L., and Mugiono. 2006. "Yield Potential Improvement of Cimelati Rice Variety through Mutation Technique." The Treatise of Scientific Seminar on Application of Isotopes and Radiation, Application of Isotope and Radiation Technology Center, Jakarta. Accessed July 2016. http://digilib.batan.go.id/e-prosiding/File\%20Prosiding/Kes ehatan/Patir/artikel/Lilik-harsanti-dan-Mugiono205.pdf.

[10] Sobrizal. 2016. "Potential of Mutation Breeding in Improvement of Indonesian Local Rice Varieties.” Jurnal Ilmiah Aplikasi Isotop dan Radiasi 12 (1): 23-35.

[11] Medio, V. S., Haris, A., Chatarina, Y., and Syamsi, A. 2012. “Annual Report 2012.” The National Nuclear Agency, Indonesia. Accessed March, 2017. http://drive.batan.go.id/kip/documents/Laporan_Tahunan _Batan_2012.pdf. (in Indonesia)

[12] Sasilakala, R., and Kalaiyarasi, R. 2010. "Sensitivity of Rice Varieties to Gamma Irradiation.” Electronic Journal of Plant Breeding 1 (4): 885-9.

[13] Daeli, N. D. S., Putri, L. A. P., and Nuriadi, I. 2013. "The Influence of Gamma Irradiation to Mungbean That Planted in Saline Condition.” Online Journal of Agrotechnology 1 (2): 227-37.

[14] Gnanamurthy, S., Mariyammal, S., Dhanavel, D., and Bharati, T. 2012. "Effect of Gamma Rays on Yield and Yield Components Characters $\mathrm{R}_{3}$ Generation in Cowpea (Vigna unguiculata (L.) Walp.).” International Journal of Research in Plant Science 2 (2): 39-42.

[15] El-Degwy, I. S. 2013. "Mutation Induced Genetic Variability in Rice (Oryza sativa L.)." International Journal of Agriculture and Crop Science 5 (23): 2789-94.

[16] Sianipar, J., Putri, L. A. P., and Ilyas, S. 2013. "The 
Effect of Gamma Irradiation on Mungbean (Vigna radiata L.) That Planted on Drought Condition.” Online Journal of Agrotechnology 1 (2): 136-48.

[17] Widyantoro, Utomo, R., Kamal, M., and Gunawan. 2012. "Effect of ${ }^{60} \mathrm{Co}$ Gamma Ray Irradiation on Yield and Protein Content of Maize.” M.Sc. thesis, Faculty of Animal Husbandry, Gadjah Mada University, Yogyakarta.

[18] Dehpour, A. A., Gholampour, M., Rahdary, P., Talubaghi, M. R. J., and Hamdi, S. M. M. 2011. "Effect of Gamma Irradiation and Salt Stress on Germination, Callus, Protein and Proline in Rice (Oriza sativa L.).” Iranian
Journal of Plant Physiology 1 (4): 251-6.

[19] Ashwar, B. A., Shah, A., Gani, A., Rather, S. A., Wani, S M., Wani, I. A., Masood, F. A., and Gani, A. 2014. "Effect of Gamma Irradiation on the Physicochemical Properties of Alkali-Extracted Rice Starch.” Radiation Physics and Chemistry 99: 37-44.

[20] El-Sherif, F., Khattab, S., Ghoname, E., Salem, N., and Radwan, K. 2011. "Effect of Gamma Irradiation on Enhancement of Some Economic Traits and Molecular Change in Hibiscus sabdariffa L.” Life Science Journal 8 (3): 220-7. 